\title{
Not a Country or a Stereotype: Latina LDS Experiences of Ethnic Homogenization and Racial Tokenism in the American West
}

\author{
Brittany Romanello
}

Citation: Romanello, Brittany. 2021.

Not a Country or a Stereotype: Latina LDS Experiences of Ethnic

Homogenization and Racial Tokenism in the American West. Religions 12: 333. https://doi.org/ $10.3390 /$ rel12050333

Academic Editors: Matthew Bowman, Caroline Kline and Amy Hoyt

Received: 12 April 2021

Accepted: 6 May 2021

Published: 11 May 2021

Publisher's Note: MDPI stays neutral with regard to jurisdictional claims in published maps and institutional affiliations.

Copyright: (C) 2021 by the author. Licensee MDPI, Basel, Switzerland. This article is an open access article distributed under the terms and conditions of the Creative Commons Attribution (CC BY) license (https:// creativecommons.org/licenses/by/ $4.0 /)$.
School of Human Evolution and Social Change, Arizona State University, Tempe, AZ 85287, USA; bromanel@asu.edu

\begin{abstract}
The Church of Jesus Christ of Latter-Day Saints (LDS), also called Mormonism, has experienced rapid changes in its US demographics due to an influx of Latinx membership. The most recent growth in the US church body has been within Spanish-speaking congregations, and many of these congregant members are first or 1.5-generation immigrant Latinas. Using ethnographic data from 27 interviews with immigrant members living in Utah, Nevada, and California, LDS Latinas reported that while US Anglo members did seem to appreciate certain aspects of their cultural customs or practices, they also reported frequently experiencing ethnic homogenization or racial tokenization within US Church spaces and with White family members. Our findings indicate that the contemporary LDS church, despite some progressive policy implementations within its doctrinal parameters, still struggles in its ever-globalizing state to prioritize exposing White US members to the cultural heterogeneity of non-White, global LDS identities and perspectives. Latina LDS experiences and their religious adjacency to Whiteness provide a useful lens by which researchers can better understand the ways in which ethnic identity, gender, legal status, and language create both opportunities and challenges for immigrant incorporation and inclusion within US religious spaces and add to the existing body of scholarship on migration and religion.
\end{abstract}

Keywords: Latinas; US immigration; ethnic homogenization; racial tokenism; religious politics; Mormonism

\section{To Be a "Swinging Door"}

I have likes and dislikes you know. I don't like soccer. I can't dance to save my life ... [But] my in-laws come to me and assume I like it. They ask, 'what does this Mexican holiday mean?' ... I don't know all the answers because I [also] grew up here. I need them to see me as a person, and not a country or a stereotype.

\section{Veronica, LDS member, Utah}

Veronica $^{1}$ is an LDS immigrant who moved back and forth between the US and Mexico until she was sixteen years old. Now twenty-nine, she lives in the greater Salt Lake City, Utah, area with her US-born White husband and their two children. She described to me the oft-tense relations with her in-laws, who have consistently homogenized and tokenized her Mexican identity since her marriage into the family. She found this frustrating, especially because after years of her presence within the family, the frequency of these macroaggressions and expectations for her to know everything about Mexico have not decreased very much. In our 2018 interview, she characterized herself as a "swinging door", or feeling as if she had to be some type of ambassador living between two countries, cultures, and distinct ways of thinking. Although she appreciated this multicultural ability within herself and saw its benefits, she also described numerous painful interactions with US Americans, including her White LDS in-laws, in which she was stereotyped and belittled because of her phenotype and immigrant status. Veronica cited that this racialization and stereotypes about Latinidad $^{2}$ has made it difficult to combat social assumptions as she navigates family 
and Church relationships in Utah, the epicenter of the Church of Jesus Christ of Latter-Day Saints (LDS), also called the Mormon Church.

Although Veronica shared with me many instances of discrimination she has faced since making Utah her permanent home, she also emphasized the joy she feels in practicing and raising a family in the Church, which she believes is beneficial to her life and well-being. She asserts now, more than ever, that the doctrine of the LDS Church is true. However, she struggles to translate this spiritual testimony into a tangible, consistent feeling that other White US-born church members accept her because of the constant commentary and racialization of her body and cultural practices. Veronica is not alone in this sentiment. More than $70 \%(n=20)$ of the women I interviewed throughout this study directly expressed similar experiences to Veronica concerning marginalization based on ethnicity, race, or immigrant status in US Church spaces. Additionally, many participants echoed Veronica's feeling of being a 'swinging door' between two cultures. Previous scholarship has demonstrated that this perception of 'in-betweenness' is a commonly reported occurrence among first and 1.5-generation Latina immigrants like Veronica (Menjivar 2002; Holloway-Friesen 2008; Burciaga 2016). However, there is less information about how Latina immigrants navigate these dualities within religious social contexts, especially within globalized faith networks like the LDS Church.

In recent years, the primary source of new growth in the US LDS church body has been within Spanish-speaking congregations, and the majority of these members are women like Veronica-immigrants who seek acceptance of their ethnic identities and cultural values as a part of their religious practice (Vega 2019; Romanello 2020). Other American-born religions have experienced similar changes in their US demographics due to recent influxes of Latin American immigration that have brought in new membership (López-Sanders 2012; Alonzo 2016; Reyes 2016). This racial and gendered diversification within historically Anglo- and androcentric religious bodies has led to increased tensions between new immigrant groups and US-born congregants. Within the context of the LDS Church body, these ideas of who 'belongs' and how much immigrants should assimilate into a host society could be one reason for the emergence of extreme conservativism and nationalist rhetoric within many US Mormon social circles, including support for the alt-right movement. Deseret Nation (nicknamed DezNat), a group of ex-LDS and current LDS members, uses Mormon doctrine and the views of previous Church leaders on race and gender to justify white supremacy, homophobia, and rigid gender norms (Dalrymple 2017; Brooks 2018, 2020; Hitt 2019).

This paper begins by addressing the ongoing history of ethnic relations and racial politics in the US LDS religious community, utilizing both past institutional policy and doctrinal ideologies of racial hierarchies, as well as the personal attitudes and behaviors of individual members, to better understand LDS and Mormon social spaces and ethnoreligious identity construction. I then use ethnographic interview data collected during my 2018 project with LDS Latinas in the American West to explore how these histories influence individual women's experiences within the modern US Church, including how they experience ethnic homogenization and racial tokenism. Finally, I articulate how Spanish-speaking congregations serve as incorporation pathways that allow women the agency and freedom to develop their ethnoreligious identity formations outside of the overarching White and patriarchal influence of the Church institution. The ways in which immigration, national identity, race, and gender create both opportunities and challenges for Latina immigrant incorporation into Anglo-dominant LDS Church spaces is an important contribution to the existing bodies of migration, gender, and religious scholarship. I feel honored that Veronica and other Latina mothers living in the American West were willing to share their stories with me, and I hope that by doing so, emerging research on global LDS experiences can subvert the idea that the predominant voices of Mormonism continue to be almost exclusively White, male, and US-born. As Veronica said, "There's danger in telling only one side of a story". 


\section{2. "All Are Alike unto God:" Race, Ethnicity, and Whiteness in LDS History and the US}

In general, church communities have served as organizational power structures within society and as spaces created for personalized, subjective faith experiences. One central factor permeating conversations regarding race, ethnicity, and Whiteness in both LDS and US history is how Church demographics have rapidly changed over the last fifty years. This is critical to discussing contemporary social contexts and the construction of ethnoracial identity in broader Mormonism. The Church of Jesus Christ of Latter-day Saints began as a small, Anglo-American religious movement in the northeastern US in 1830. In 1847, persecuted and destitute Mormons settled in the Rocky Mountains, then a part of Mexico. Since that migration in the late nineteenth century, Mormon membership has grown from thirty thousand to almost seventeen million members worldwide, with most membership residing outside the US and Anglo-European racial categories (Gooren 2007; Cragun and Lawson 2010; Decoo 2013). Most of the new growth within areas of the American West with high LDS membership, such as Utah, Idaho, Arizona, Nevada, and California, consists of Latina mothers and their families, making the presence and service of Latinas within US Church spaces especially important. In fact, according to recent public Church records, around four in 10 Mormons worldwide are of Latinx or Hispanic origin as defined by the US Census Bureau, with Spanish-speaking congregations called "wards" now the main source of growth in the US Church (Romanello 2020). In addition to increased global membership and strong pan-ethnic Latin diversity, studies have also shown that LDS women's participation and membership now outnumber those of men within US congregations, despite the highly patriarchal nature of the Church's institutional power structures (Phillips et al. 2011; Birger 2015; Riess 2019). This change from a historically small, White US religious movement to a global, diverse Church that predominantly consists of nonwhite membership is important in contextualizing the central tensions of race, gender, and migration in LDS contexts.

Paul Reeve (2015) chronicled the various ways in which nineteenth-century constructions of Whiteness in the US created tensions of identity and belonging for the LDS Church as it battled for its collective national identity and acceptance. There was strong and often violent opposition to the LDS Church's distinctive cultural, doctrinal, and political practices, one of which was baptizing and integrating non-White people into the early Church long before other Protestant groups were willing to do so. The fear and rejection of LDS theology and their practices led to what Reeves describes as a holistic loss of both spiritual and physical Whiteness within this Anglo religious society (Reeve 2015). This struggle for social acknowledgment and affirmation was compounded by the fact that the LDS church practiced both of the 'pillars of barbarism' outlined by the then-Republican party: polygamy and the enslavement of Indigenous peoples (Reséndez 2016). These practices and the increasingly insular nature of LDS Church communities after multiple Westward migrations led to increased marginalization and rejection of Mormonism within mainstream US society, with Mormonism, like Jews, having been categorized as a "liminally White" ethnoreligious group (Moshin and Crosby 2018). As a counteraction to this racial "othering" and societal disenfranchisement, including multiple rejections of petitions for US statehood, the LDS Church undertook decades of institutional rebranding to realign itself with White racial assimilative practices and ideologies (Alexander 1996; Bushman 2008; Crosby 2011; Colvin 2015; Mason 2018).

Beginning in the nineteenth century and continuing into the twentieth, Mormonism adopted mainstream US racial views that included colonial constructs of White exceptionalism (Murphy 1999; Smith 2015). This included the way in which LDS scripture, including the Book of Mormon, began to be interpreted, using racialized language that denoted lighterskinned complexions as more righteous, whereas darker-skinned people, often called Lamanites, required stronger missionary work efforts, and saving by more 'white and delightsome' peoples (Mauss 2003; Romanello 2020; Hernandez 2021). Modern interpretations suggested that Latin Americans and Indigenous descendants were of 'Lamanite' 
heritage, whereas groups like Pasifika or Polynesian communities were spiritually adopted into Nephite lineages (Aikau 2012). Religious Studies professor Max Perry Mueller (2017) discussed in his book Race and the Making of the Mormon People how the LDS leadership attempted to dually prove the Church's social and spiritual exceptionalism as the one true religious community but fell far from racial and ethnic universalism and inclusion. Many authority figures began teaching that pre-mortal sins or association with particular tribal lineages cursed other races (Mueller 2017). Around the time my parents were born, in the early 1960s, it was common in US church spaces to hear race and racial hierarchies discussed as a natural consequence of pre-mortal decision-making rather than a colonial social construct. For example, LDS apostle McConkie and Kelling's (1966) book Mormon Doctrine wrote the following:

All races of men stem from certain common ancestors. [ ... ] resulting in differences in appearance and spiritual aptitude ... know the circumstances under which the posterity of Cain was cursed with what we call negroid racial characteristics. The Book of Mormon explains why the Lamanites received dark skin and a degenerate status. If we had a full and true history of all races and nations, we would know the origins of all their distinctive characteristics. [ ... ] The race and nation in which men are born in this world as a direct result of their pre-existent life.

McConkie's reference to Cain comes from interpretations of the Bible (which are not exclusive to LDS doctrine) that insinuate that Cain, the son of Adam and Eve, the first man and woman created by God, turned physically dark because he murdered his brother Abel. For centuries, this curse was interpreted literally, and this narrative has been used in many historical religious and political contexts as a justification for slavery, violence, and social institutional prejudice towards Black and dark-skinned populations. Numerous case studies have shown that this was also the case within the LDS Church (Garrett 2010; Mason 2018; Stuart 2018; Jones 2019; King 2019). Although the mark of Cain (blackness) was long considered a curse with no reform until the LDS Church gave Blacks full membership privileges in 1978, Lamanites' descendants were often considered a homogenous group that could be saved, whitened, and reformed through conversion to Mormonism (Mauss 2003; Garcia 2015, 2020). Since then, the racialized terms and identity categorizations of the "seed of Cain" and "Lamanite" have both stabilized as the Church has heavily increased its global engagement and membership of non-White peoples. However, the Latina participants in my study struggled to reconcile the historical uses of "Lamanite" and racialization with their contemporary experiences because these histories of race do affect their lived experiences as Church members.

One point that many participants noted when articulating their experiences with discrimination in LDS Church spaces was the overt cognitive dissonance and confusion regarding US cultural notions considered culturally "appropriate" or politically "correct". For example, one member named Ines, who came from Mexico to the US as a child, spoke about her experience as a missionary in Idaho, where she served because she was living in the US undocumented. When local members who were citizens found out that she did not have legal status, they praised her for being so "assimilated", but condemned her for not "fixing her situation correctly" before serving a mission. "They didn't try to understand my situation", Ines told me from across the table we sat at, noting that the Church institution knowingly allows undocumented missionaries to serve stateside in the US, facilitating the means and often providing financial help to complete a mission. She continued: "As long as you were an assimilated person of color you were fine, but they were conservative in my area. It was a hard [reality] check". Others who shared experiences like those of Ines cited how uncomfortable these assimilative ideas were as they crept into their worship spaces and social interactions, especially as the LDS Church continually positions itself as politically neutral and racially inclusive. Many women used phrases like "We are all supposed to be seen/viewed/treated as children of God", or "Heavenly Father/God doesn't care that I am an immigrant, why do the (White, American, or gringo) 
members here care so much?" These comments were referencing the perceived fixation that Anglo members seemed to have on Latina members' legal status, English abilities, language use, parenting approaches, and cultural practices both in and outside the home.

Officially, the LDS Church website states the following: "The gospel of Jesus Christ is for everyone. The Book of Mormon states, 'black and white, bond and free, male and female; ... all are alike unto God, this is the Church's official teaching' (2 Nephi 26:33)." This quotation is from the Second Book of Nephi within the compendium of the Book of Mormon. The phrase "all are alike unto God" is used to promote racial and ethnic harmony in Church contexts. President Ahmad Corbitt is a US Church leader who currently holds the position of First Counselor in the General Young Men's Presidency, a worldwide LDS auxiliary group for young boys aged from 12-18. He is also one of the few Black men serving in a General Auxiliary position within the LDS Church institution. In a recent talk on race and ethnic relations within the Church, he stated, "The Church of Jesus Christ of Latter-day Saints is one of the most successful international organizations in the world at promoting brotherhood and sisterhood among all races and ethnicities". In recent years, this type of focus has been more and more common among members of the Church as racial and socioeconomic tensions rose during the Trump presidency. Most Latinas I spent time with during the study shared President Corbitt's view of Church doctrine and ideologies. However, as an institution, local and worldwide Church authorities do not universally regulate the application of the LDS's spiritual attitude that "all are alike unto God" and the promotion of "brotherhood and sisterhood among all race and ethnicities". It is highly dependent on what many colloquially call "leadership roulette", or the discretionary attitudes of each local leadership to decide how to interpret what is apolitical, inclusive, and harmonious within their spiritual jurisdictions. The LDS Handbook only recently addressed racism and prejudice as a "sin", as part of a formal code of conduct within the Church in mid-December of 2020 (Mccombs 2020).

Because of this so-called "leadership roulette", which relies on volunteer lay leadership service, individual experiences within LDS congregations can vary widely and are highly dependent on geographical location and the sociopolitical landscape in a given area. Mormon studies scholars such as Melissa Wei-Tsing Inouye and Ignacio Garcia have both characterized how perceived cultural differences alter access to resources and create hierarchal power dynamics within LDS wards, ranging from subtle bias to more explicit discrimination (Colvin and Brooks 2018). These factors could also explain why racial tension and marginalization continue to be pervasive barriers preventing Latina immigrant women from feeling that they truly belong in Anglo-centric US Church spaces, despite the Church institution's official calls for inclusivity and acceptance. The findings of my ethnographic study show that despite Latinas' long-standing presence, service, and dedication in Church spaces both in their native countries and in the US, they are continually experiencing othering through experiences with ethnic homogenization and racial tokenism, even if they marry into White LDS families. The following sections discuss both women's encounters with the Church institution and its members, and how discretionary and geographical interpretations of official Church doctrine result in inequitable treatment of non-White women, in this case, Latina migrants. In the last section, I demonstrate that Spanish-speaking congregations or "wards", serve as spaces for spiritual and social sovereignty from racial, ethnic, and legal status discrimination.

\section{3. "They Serve Tacos for the Sacrament:" Experiences of Ethnic Homogenization}

Past research on religious networks has demonstrated the importance of church communities in facilitating collective spaces for inclusion, belonging, and resources within sending and receiving migrant communities (Menjivar 2006; Levitt and Jaworsky 2007; Hondagneu-Sotelo 2008; Sarat 2013). Furthermore, for many immigrant communities, religion is a constant in their changing world, which is full of highly variable structural and socioeconomic vulnerabilities, where they can be safe to maintain traditions from their homelands and integrate with others. Immigrant religion is both a practice of beliefs and 
a cultural manifestation of their ethnic, linguistic, and national origins. In the US, both cultural background and religious practice are used to define the parameters of immigrant ethnic identity. According to Chafetz and Ebaugh (2000), this is an "ethnoreligious" identity. This makes for an interesting case for Latina immigrant Mormons, who I see as participants in a dual ethnoreligious context-one that honors the traditions of their sending countries through their contribution in shaping US Mormon religious practices. However, attempts to integrate migrants within a host society can also create contention and isolation if those host societies treat immigrant groups as inferior based on differences in areas like ethnic identity or cultural practices (Lawson 1998; Ong 2003; Hinojosa 2014; Waninger 2015; Welborne et al. 2018).

Veronica, discussed in the introduction of this article, described one such experience to me in a second conversation about her interactions with majority White and Englishspeaking wards. "What, are you serious?", I reacted when she told me, struggling to keep my composure and neutralize my voice and facial expressions. It was not that I did not believe her; I was embarrassed and horrified. 'Yes, really", she confirmed again, "It happened". When visiting a church in Richfield, UT, with her in-laws one Sunday, she and her husband had searched for a Spanish ward to attend. One older White man looked at Veronica and laughed, suggesting that she would like their Spanish ward, because "they serve tacos for the sacrament". The LDS sacrament, like many other religious ordinances, is sacred. As a weekly act, consisting of consuming bread and water as a representation of the blood and body of Christ, it represents a renewal of covenants or promises that Church members make with God when they are baptized. The insinuation that the Spanish ward would eat tacos for the holy rite of sacrament deeply offended not only Veronica but her husband as well. This experience, along with other experiences of ethnic homogenization that I will share later, has caused similar pain for Latinas who have experienced this kind of marginalization in both private and domestic spaces that they consider sacred.

One barrier to successful incorporation that mothers often cited in our interviews was ethnic homogenization by American-born Church members. One mother, Naomi, was a professor in her home country of Ecuador. As a faithful convert with excellent educational and Church network resources, she was able to follow her children to the US after her divorce, overstaying her visa while working for an LDS family in California. She expressed that she was grateful for the life she has now after migrating:

If I had stayed in Ecuador, I wouldn't have been able to do it. What I made in my country in one month, I make here in a week. Those resources [permit] me to be able to help my three children. I am immensely grateful.

However, Naomi also noted that these resources came at a cost—she was often the target of racism both in public and private social spaces. She told me quietly:

I have had a lot of problems with racism. Sometimes when I go out [to shop or with friends] people have called me "Mexicana" because they think that there is only Mexico. Sometimes I would laugh a little at the other [Latino] people that said that. It's nothing against Mexico, but that's not my [background]. But for example, if I go somewhere [like a store] that's just North Americans, they look at me and they will attend to me last.

Naomi's words highlight how everyday situations like shopping or going to eat in southern California, although boasting a large Latino population, still resulted in categorization into the conglomerate, ethnoracial category of "Mexican", and because of this categorization, she was discriminated against. When I asked Naomi why she thinks people assume she is Mexican, she said she thinks many Americans "are not taught" the nuances of different Latin American cultures. She noted similar experiences after moving to Utah as well. "I think it's the US in general", she said, "but also, the Church member's forma de ser (way of being) is reflected in that, right?".

Veronica's recent experience of ethnic homogenization from her suegra (mother in law) seems to affirm Naomi's assertions. Not too many Christmases ago, Veronica told 
me about what we decided should be called The Pajama Disaster: "She gave me pajamas with llamas on them. They were cute, but when my suegra said, oh these made me think of you [because] you are from Mexico. I said llamas are from Peru if you're making that connection". This interaction became extremely contentious when Veronica's mother replied, "Oh well it [Mexico and Peru] is the same thing", to which Veronica, frustrated, retorted: "That's rude. We don't have the same anything, like not even food". This brief but telling interaction exacerbated what both Veronica and Naomi already knew-that many White LDS members, including their own families, had not made the effort to learn the distinctions between different countries and their cultures. This hurt Veronica, making her feel like her distinct values and ethnicity did not matter to her in-laws. Other mothers expressed similar interactions when attending ward activities where their Spanish-speaking congregations would do activities with the English-speaking ones.

Julissa, a Salvadoran-Ecuadorian mother of two, is married to a White man and now living in Idaho. However, many of the experiences she shared came from her childhood home in the suburbs of West Salt Lake City, where both her parents lived undocumented for some time. One particular Church activity she shared was a youth dance, often put on for LDS youth aged from 14-18. The theme of the dance, taking place over the first weekend of May, was Cinco de Mayo-themed. This holiday, primarily celebrated in Puebla, Mexico, is relatively unknown in other countries, but is widely celebrated by White Americans. Julissa described to me that this youth dance was one of many LDS wards parties or celebrations hosted by English wards that used Mexican imagery such as long mustaches, ponchos, sombreros, and colorful Mexican piñatas. She described how White youth, including some schoolmates, would line up, taking pictures with said items, inviting Julissa to be in their picture because of her Latina appearance. Julissa said she was deeply hurt by these displays of appropriative attire, but struggled with how to articulate her hurt, especially after a leader told her there was no reason to be offended. Beginning to cry while talking about such a painful experience, she said, “But I was offended! ... This celebration wasn't for $m e$, right. I am not even Mexican. Mexicans don't even wear those things really [so], I see White people in ponchos or with mustaches [and] I think, are we a joke to them? Are we a costume?" Julissa has quite a few versions of this same type of story over the years. When I asked her how she now handles it when she sees culturally insensitive costumes at Church parties, she shrugged. She told me, "I just get too tired". I nodded in agreement with her. It seemed that Julissa was tired of trying to explain to Anglo Mormons in Utah and now in Idaho how she, her fellow Mexican LDS members, and other non-White groups, were not a costume or a one-size-fits-all ethnic ensemble.

In inquiring further about these interactions between Spanish-speaking wards and their English counterparts, I spoke with Jane. Jane is a Mexican mother of three who has lived in both Idaho and Utah since immigrating to the US. She was hesitant to share anything considered negative regarding her interactions with Anglo Church members, especially because her husband was a high-ranking local Church leader in the area at the time of our interview. When reminded that her identity would remain anonymous, however, she expressed some of her concerns with ethnic homogenization since moving to the US:

The cultures are very different between Americans and Latinos. I have [White] friends who are very loving, and there are others who you feel like they don't want to know you. There is this space. I like that Americans are very organized and very orderly, punctual ... they care a lot about their rules! But I wish that Americans would see our distinct cultures and good qualities- the ones both parties can appreciate.

Jane's reference to space was very applicable, in one way or another, among all the women I interviewed. Each participant had her way of articulating not just the physical distance or difference they felt in interacting with the many US-born Church members, but also the emotional dissociations they often encountered as well. Although none of the mothers wished to make blanket statements regarding all Anglo-American or US citizen 
members, there was plenty of evidence between all of them that Church communities throughout the American West can and must do much better at honoring, respecting, and educating themselves about the cultural and ethnic differences of immigrant members, rather than homogenizing their identities. Along with ethnic homogenization, racial tokenism is another topic that came up frequently in my interviews with LDS Latinas.

\section{4. "We Are Either a Novelty or a Nuisance to Them": Experiences of Racial Tokenism}

Tokenism has been defined as a social mechanism that a dominant group may use to showcase or perform diversity or inclusion in a public way, without taking appropriate steps to understand, consider, or make equal the unequal experiences of that tokenized group within a larger group setting (Niemann 2016). In the context of the LDS Church, the historical usage of Lamanite, "seed of Cain", and Nephite, or other scriptural lighterskinned or Israelite missionary work as a mechanism for redemption or saviorhood, as constituting a unique brand of problematic religious tokenism. BYU Professor Ignacio Garcia (2015) discussed this romantic tokenization of Latino Mormons in a broad sense, stating in his own experience as a former lay leader and current professor that in general LDS members seem to appreciate the performative aspects of Latinidad such as music, food, or dance, but that this appreciation is shallow because of its conditional and fleeting nature. The Latinas in my study sample came from various countries, such as Ecuador, Mexico, Peru, Argentina, and Guatemala, and many reported tokenization in spaces where they were the only Latinas, acting as the "swinging door", or sole educator or cultural translator for White members, while at the same time finding herself ignored or disrespected at the slightest inconvenience.

One example of this is Luisa, who arrived from Mexico in New York City when she was 19 years old and moved to Utah after joining the Church later in life. We met again after our original interview, and her adult daughter, Arely, joined us for the conversation. Arely was born in the US, and was especially interested and engaged in listening to her mother's experiences during our follow-up dinner. When we discussed tokenism, Arely exclaimed, "This is what my mom and I talk about all the time ... (Sighs) ... I like white boys you know but, I am not sure I want to marry one. [With white members] it seems like we are either a novelty or nuisance to them!" Luisa, although reluctant to be as direct as her daughter on this topic, nodded in agreement. "Yes, it has felt like that sometimes". When I asked them both to elaborate, they mentioned that many LDS members love Mexican or pan-ethnic Latinx foods, and love watching them dance at Church cultural events, but do not take the time to know them as people. Arely brought up an example, prompting her mother to share their experience at a combined Church event that included both the Spanish- and English-speaking congregations in their neighborhood.

Luisa and Arely arrived thirty minutes late to the activity, grabbed a plate of food, and sat down to eat. Luisa said that a few minutes after, a White member appeared in front of them, and as they were eating, he began to take everything off the table in front of them, including trying to take their glasses they were still using. When directly addressed as to what they were doing, the member said, "It was because they had a 'schedule' the ward activity members wanted to follow, and we had shown up too late", Arely rolled her eyes recalling his words.

But that's just rude, right? Like we would never do that in a Latino activity, like, ever! And honestly, I can't think of any white members doing that to someone in the English-speaking ward ... were we invisible?

Arely and Luisa's experience at the ward activity highlights the dissonance many Latina members feel when interacting with White members. In many Latin American cultures, including Mexico, food and the time set aside for sharing a meal is very respected, and even more special when you have invited guests. Rushing someone through a meal is considered highly inconsiderate and a sign that you do not want your guest to feel welcome. This scenario elucidates how seemingly 'innocent' actions by one White member highlight 
the constant struggle that women like Luisa and Arely have with the aforementioned cultural space between Latinx and White Church members that Jane mentioned.

Cecilia, a twenty-eight year old mother of two in Utah, was quick to tell me about her experiences moving from a Latinx-dominant neighborhood in Chicago to Salt Lake City as a grade-schooler after her parents converted to the Church in Illinois:

Girl! Let me tell you, when we got here, it was just all White. I didn't know who the pioneers were or Utah culture. Nobody could say my name right, not teachers or students. They all asked if I like burritos. There just wasn't anyone around me except my family that was like me. I ended up having to go to counseling in elementary because it was so hard feeling alone.

Cecilia told me about many experiences like this growing up when her heritage was tokenized within her new predominantly Mormon community. She told me that this tokenization was also manifested while she was a young adult, navigating the local LDS dating pool:

I had a date with a returned missionary who served his mission in Mexico. [He] told his friends after our date, "now I can say I made out with a Mexican girl!" ... Like I was just a check-off of his list ... [so] there was this stereotype of being Latina. As soon as I had human emotions and feelings, these white guys maybe got bored of me [because] I was supposed to be reserved and submissive, and instead, they would say, "Oh I didn't think Latina women were so assertive".

Here Cecilia touches on another aspect of racial tokenization: exoticization and hyper sexualization of non-White women's bodies. This is a well-documented aspect of tokenization research that places race in a context with sexuality, insinuating that women of color have higher sex drives and are more promiscuous and 'easy' to negotiate sexual acts with (Molina-Guzmán 2010; Spell 2017; Biefeld et al. 2021). Even amidst the conservative sexual politics of the LDS Church, Latina members were not exempt from White men racializing them or sexualizing their personalities and bodies. Cecilia cited this sexualization as a primary reason why she prioritized marrying another Latino. Whether it was her phenotype, her dietary preferences, or a "spicy Latina" trope that assigned personality traits and presumed sexual behaviors to her Latinidad, Cecilia's experiences with White LDS members characterize how damaging experiences with tokenization can be for young immigrant women, especially within the religious sociocultural contexts that are supposed to offer safety and acceptance.

After our interview, Cecilia referred me to one of her longtime friends, Camila, to discuss Camila's resistance against ethnic homogenization and tokenism. Camila is originally from Argentina and moved to Utah during her elementary school years. She described an instance with her teacher during her first year learning English:

I was one of two people of color in my third-grade class. Not sure how long I'd been here [in the US], but I didn't understand what my teacher was saying. She wanted me to say "here" when she called attendance and was pissed I wouldn't [speak] English. The other Latina girl wanted to help but didn't know how.

Camila said that memory stuck with her because, although it may not seem like a "big deal" to a lot of others, it was her first memory of being singled out for her differences. She didn't understand why her saying "here" in Spanish mattered. Now as an adult and fifteen years later, she said she understood: "They [White teachers] wanted me to assimilate... But I couldn't fit the mold". She then expressed the irony of the pressures she faced to do things in the "correct" American way, only to be told that her race and immigrant status was considered a barrier for her as she prepared to apply for college. Camila described a meeting she had with her junior high school counselor.

The counselor [said] to my parents 'don't worry about pushing her too hard. You should consider going to cosmetology school ... Don't waste your money at university.' Race probably played a bigger role than gender, to be honest. Maybe I'm cynical but at that point, I wasn't surprised that my White, Mormon 
counselor looked at me (a Latina) like that ... so I resisted. They thought that I couldn't go to college, well, I have my Master's now.

Camila's experiences with racism and tokenization within education contexts offer a crucial perspective. Many findings on first- or 1.5-generation Latina migrants show that after migration women are usually likely to gain more power in the household (Hondagneu-Sotelo 1994; Espiritu 2001, 2003), challenge or shift gender roles (Toomey et al. 2015; Hondagneu-Sotelo and Messner 1994), and further their education and skill sets (Hagan et al. 2015). However, as Camila describes, because of both racial and gender constraints within their predominantly Mormon community, Camila was discouraged early on by US Mormon leadership or LDS peers or educators from seeking higher education opportunities such as four-year college degrees or graduate school. A high number of interview respondents, over $50 \%(n=14)$, expressed similar instances in which the combination of race and gender was utilized against them, creating increased social and educational barriers towards upward mobilization in their religious communities. One place all of these women expressed finding refuge from experiences with tokenization was within the Spanish ward, where they all cited a preference for attending Church meetings and activities.

\section{5. "Es un Sentido de Familia": Spiritual and Social Sovereignty in Spanish Wards}

Sociologist Jazmin Muro conducted years of research regarding Latino and White social relationships in Southern California. Her work in dual-language high schools (Muro 2016) showed that even though Latino and White adults of all socioeconomic backgrounds were able to be polite, with no outward racial hostility through various social settings, they did not seem to form meaningful bonds or cross ethnoracial boundary lines more than necessary. She also found that even though parents shared the same goals for their children, like bilingualism and future collegiate success, both Latino and White parents did not go beyond casual interactions to develop reciprocal contact that would increase community ties. She characterizes these behaviors as "symbolic integration", meaning that while Latino and White parents in the community socialized willingly because of a common denominator, such as a mutual interest in their children's schooling, constructed racial boundaries were still heavily present between them. The few previous articles that specifically evaluate Latino-White relations within the context of the Mormon Corridor have shown that a similar kind of symbolic integration has existed for some time between Spanish and English wards, with members coming together for area activities and conferences because of a common interest in the LDS Church. However, the attempt to do more than symbolically integrate Spanish and English wards in the past has created multiple instances of institutional marginalization and social tension for Latinx and Anglo LDS populations. (Embry 1997; Garcia 2018; Vega 2019; Romanello 2020). This case study and Muro's illustration of symbolic integration is an important context that can help us to understand some of the factors that cause Latina women to prefer pan-ethnic Spanish speaking wards to English ones, even if they are bilingual.

I found that in addition to engaging in symbolic integration, immigrant communities enhance their worship experiences and social closeness by creating or reshaping church congregations so that they appear more similar to themselves. Sociologist Sarah Stohlman (2007) called this reshaping of immigrant religious spaces, "congregational homophily." Her case study found that immigrant populations who worshipped with other co-ethnics similar in age or gender felt a more intimate and fulfilling connection to their religious practice. Laura López-Sanders (2012) further explored this preference for worshipping with co-ethnics along with the establishment of ethnic hierarchies among Colombian, Guatemalan, and Mexican migrants in the US Bible Belt. While all three groups found common ground through a shared immigrant experience in highly White and Anglo religious spaces, inter-ethnic differences, education levels and colorism created contention when juxtaposed against their expectations and interactions with Anglo worshippers. These practices of congregational homophily and immigrant negotiations in countering 
Anglo influences in church spaces are also consistent with the historical contact of many Latinx Mormons with the US Church body. Despite inter-ethnic differences or tensions, the women in my sample still largely prefer to attend a pan-ethnic Spanish ward over an English one. Fifty-seven-year-old Elisa from Argentina told me that Spanish speaking wards have a "sentido de familia", or a "feeling of family", meaning that the women felt increased belonging, comfort, and a general sense of being able to be wholly themselves at Spanish wards, despite the occasional interpersonal conflicts that were "bound to occur." Elisa elaborated, saying, "I didn't have to explain myself there ... [Other] women got it. They understood a lot of my situation." Elisa refers here to the idea that other Latinas at church had a foundational and shared understanding of her immigration and mothering experiences and stressors, making it easier to feel supported and ask for what she needed. The majority of other interview participants $(n=22)$ expressed similar feelings.

When asked for additional articulation about their Spanish ward preference, women like Jane agreed with Elisa's sentiment, and told me that she felt the cultural differences between her and the members in the English ward were just,

Too big! In the beginning, we did go to the English ward. But the wards are too big, and the culture is too different. Us Hispanos are more affectionate, like friends. They (Americans) are more reserved, they don't like getting close. They don't like hugging. Even though we love English (language), the feeling was too different.

Jane also noted that even though her family recently was able to adjust their legal status so that they could become permanent residents, this feeling of difference still lingers even as she strives to further incorporate into US society. "Even now (with my papers), it feels like the mothers in the English ward don't really like sharing the kitchen with me or the hermanas in my ward. I just always feel in the way". Jane felt that although her legal status had changed and her understanding of English had improved, she did not feel part of the camaraderie of the English ward, and felt much more comfortable attending the Spanish congregation. Cecilia also was very straightforward in articulating her English ward experiences, and why she and her children now always attend a Spanish ward:

The English ward-that shit changed me. Showing my heritage was a negative thing. I was already a token in school and then at Church with my white friends. When I and my other undocumented friends realized we could be more than one thing, we didn't have to act White, everything changed. If I embrace American things, I'm not less Mexican. So duality ... I can do both. It would have been nice to be in a Spanish ward sooner because it would have been easier to be myself. I don't want to be looked at like something in a museum.

Cecilia viewed the Spanish ward as a place for pan-ethnic Latinx solidarity, where she and other undocumented Latinx youth could support each other in being more like themselves, rather than tokenized versions of what Anglo-Americans assumed they "should" be. In this way, the Spanish ward was not only a cultural refuge for Elisa, Jane and Cecilia, but also a created space of resistance. One Mexican migrant, Lara, who currently attends a Spanish ward in Southern California, expressed a similar social reasoning for choosing to attend the Spanish ward, but for her, it was also spiritual:

I had cancer. Thanks to the sisters of the Church that never left me. They were like my family because my blood family was always far away. I think [about] how lonely we immigrants are, and how much we lack our family [support].

For Lara, living with her husband and three children for so long without assistance from their relatives was devastating, but as a lifelong LDS member, she knew she could depend on her other "family" in the Spanish ward to buoy her up during uncertain times, especially when fighting for her life. She made sure to tell me that at Church she hopes we can remember: 
There are no 'immigrants' in the eyes of God. Geopolitical borders still affect us, but it is our right to be free. Many Americans put their government before God, but that is not correct. God is love, God is truth, and God is all that is contrary to laws that entrap His people. At my [ward] we do not create these divisions [among] us.

She saw her investment in attending the Spanish ward as an example of her continual commitment to her faith and her sisters. These are just a few examples of the many nuanced and complex ways in which Latina mothers are making choices about how and where to worship in the US LDS Church.

\section{A Commencement, Not a Conclusion}

An overarching finding of this paper among Latina immigrant mothers living in Utah, Nevada, and California was that although each individual's experience varied, the consensus so far has been that Latina LDS members in the American West want more from the US Church body and its constituents. Similarly to previous studies on first- and 1.5-generation immigrants, the majority of the interviewed Latina Mormons wanted their LDS religious communities to accept and celebrate their intersectional and fluid identities, which were frequently being reshaped by new social settings, political arenas, and economic contexts (Ajrouch 2004; Nabhan-Warren 2014; Baring et al. 2018). Furthermore, Millennial Latina Mormons were more overt in expressing a concerning pattern of encounters with ethnic homogenization and tokenism, which had long-term psychological and socioeconomic impacts on their sense of belonging and well-being. Almost every mother under 35 shared how they internalized the ways their heritages were shamed or fetishized within white LDS spaces. Overall, Latinas reported a strong preference for worship or socialization within pan-ethnic Spanish-speaking congregations, stating that Latinx wards provided a space for differentiating ideas of how gendered cultural and religious practices can be embodied and performed. Along with more agnostic Anglo-Americans who are unaffiliated with religious groups, immigrant groups are changing American religion by breathing new life into US congregations (Mueller 2017; Nabhan-Warren 2014; Marti 2015). These findings are affirmed by other bodies of scholarly research, which show that immigrants also have the power to change and influence US religious communities (Lawson 1998; Chafetz and Ebaugh 2000; Yang and Ebaugh 2001). These studies are useful in modeling some examples of how large ethnic or language enclaves within a religious community can alter the types of services that church communities offer to accommodate and incorporate migrants. This paper and pilot study acknowledges that Latinx populations are reshaping the trajectory of US Mormonism and that observing what kind of local accommodations are made to incorporate them is important in building upon previous migration and religious research findings.

As I now focus future projects on highlighting LDS Latinas' sociopolitical status within Church spaces in Arizona, I am aware that there is no simple conclusion about how social scientists and collective religious cultures can best address the ongoing ethnic homogenization and racial tokenism that is still taking place in US church spaces. I would like to call the end of this article a commencement rather than a conclusion. The future of research with Latina LDS members is just beginning. I am acutely aware of my responsibility as an ethnographic researcher to keep sharing complex, nuanced, and honest stories that women are entrusting me to share in hopes that the culture of discretionary racial and ethnic exclusion is addressed at every level of the US Church leadership and community. This article is just a preview of how Latina Mormon mothers find inclusion and belonging in the US Church as they enact personal agency, support pan-ethnic network development, and move forward, remaining firm in their personal faith.

By no means can a single article fully capture or illustrate the cultural heterogeneity or diverse intersections of (dis)advantages that Latina immigrants face in their journeys, and therefore further exploration into Latina LDS experiences are necessary. Further inquiries into Latinas' lived experiences could more fully illuminate how the Church 
simultaneously serves as a globalized pathway by which non-White and/or immigrant populations construct notions of personal belonging and cultural identity in Anglocentric Church spaces. As numbers within Spanish wards in the US keep growing, the impact and contributions of Latina women, who are the backbone of this growth, will continue to be of the utmost importance. I challenge the US Church institution to recognize this and advocate for structural and community change, advocating for Latina Church members and others who live and worship within the nations' socioeconomic margins, so that they may have more equitable opportunities to have their labor and contributions recognized, amplified, and be made part of the key decision making practices of the global Church.

Funding: This research received funding from the School of Human Evolution and Social Change at Arizona State University, Wells Fargo Transborder Chicano/Latino Studies Research Scholarship, and the Global Mormon Studies Research Grant from Claremont Graduate University.

Institutional Review Board Statement: This study was conducted according to the guidelines of the Declaration of Helsinki, and approved by the Institutional Review Board of Arizona State University (Study \#00008225, 29 May 2018).

Informed Consent Statement: Informed consent was obtained from all subjects involved in the study.

Conflicts of Interest: The author declares no conflict of interest.

\section{Notes}

1 All particpant names have been changed.

2 Miguel Salazar (2019) defines the umbrella term Latinidad as "a fabricated geopolitical identity that contains the complexities of immigration, colonialism, legal status, and class [ . . often] erasing Black or Indigenous experience". I recognize that in an article about distinct ethnic identity and personal experiences, using a generalized term like 'Latina' cannot fully encompass individual identity and perspective, which is one central part of why homogenization and tokenism can be so harmful to non-White and otherwise marginalized communities in the US. Ironically, despite this, all of the women I interviewed used the term Latina (and some used Hispanic) to describe themselves and their ethnoracial categorization within US racial categorizations, including LDS communities. The majority of respondents also stated that they felt comfortable using the term Latina/Latinos to speak about some generalized experiences of immigrants coming from Latin America. For this reason, I use the term 'Latina' as an identifier of ethnoreligious identity throughout the paper, acknowledging that the terms Latinidad, Latinx and Latina are products of violent European Colonization and US socioracial imperialism.

\section{References}

Aikau, Hokulani K. 2012. A Chosen People, a Promised Land: Mormonism and Race in Hawai'i. Minneapolis: U of Minnesota Press.

Ajrouch, Kristine J. 2004. Gender, race, and symbolic boundaries: Contested spaces of identity among Arab American adolescents. Sociological Perspectives 47: 371-91. [CrossRef]

Alexander, Thomas G. 1996. Mormonism in Transition: A History of the Latter-Day Saints, 1890-1930. Champaign: University of Illinois Press.

Alonzo, Monica. 2016. The Mormon Dilemma: What about Mormon Latinos? Phoenix New Times, April 3. Available online: https: //www.phoenixnewtimes.com/news/the-mormon-dilemma-what-about-mormon-latinos-6455650 (accessed on 18 December 2020).

Baring, Rito, Philip Joseph Sarmiento, Nestor Sibug, Paolo Lumanlan, Benita Bonus, Cristina Samia, and Stephen Reysen. 2018. Filipino college students' attitudes towards religion: An analysis of the underlying factors. Religions 9: 85. [CrossRef]

Biefeld, Sharla D., Ellen A. Stone, and Christia Spears Brown. 2021. Sexy, Thin, and White: The Intersection of Sexualization, Body Type, and Race on Stereotypes about Women. Sex Roles, 1-14. [CrossRef]

Birger, John. 2015. Mormons and Jews: What 2 Religions Say About the Modern Dating Crisis. Time. August 24. Available online: time.com/dateonomics / (accessed on 12 January 2021).

Brooks, Joanna. 2018. The Possessive Investment in Rightness: White Supremacy and the Mormon Movement. Dialogue: A Journal of Mormon Thought 51: 45-82.

Brooks, Joanna. 2020. Mormonism and White Supremacy: American Religion and the Problem of Racial Innocence. Oxford: Oxford University Press.

Burciaga, Edelina Muñoz. 2016. The Latino Undocumented 1.5-Generation: Navigating Belonging in New and Old Destinations. Ph.D. dissertation, University of California Irvine, Irvine, CA, USA. 
Bushman, Richard Lyman. 2008. Mormonism: A Very Short Introduction. Oxford: Oxford University Press.

Chafetz, Janet Saltzman, and Helen Rose Ebaugh. 2000. Religion and the New Immigrants: Continuities and Adaptations in Immigrant Congregations. Lanham: AltaMira Press.

Colvin, Gina. 2015. Introduction: Theorizing Mormon Race Scholarship. Journal of Mormon History 41: 11-21.

Colvin, Gina, and Joanna Brooks. 2018. Decolonizing Mormonism: Approaching a Postcolonial Zion. Salt Lake City: The University of Utah Press.

Cragun, Ryan T., and Ronald Lawson. 2010. The secular transition: The worldwide growth of Mormons, Jehovah's Witnesses, and Seventh-day Adventists. Sociology of Religion 71: 349-73. [CrossRef]

Crosby, Richard Benjamin. 2011. Which is the Wisest Course?: Political Power and Prophetic Agency in Nineteenth-Century Mormon Rhetoric. Journal of Communication E Religion 34: 1-23.

Dalrymple, Jim, II. 2017. Meet The (Alt-Right) Mormons: Inside the Church's Vocal White Nationalist Wing. BuzzFeed Nezws, March 27. Available online: https:/ / www.buzzfeednews.com/article/jimdalrympleii/meet-the-alt-right-mormons-inside-the-churchsvocal-white (accessed on 7 January 2021).

Decoo, Wilfried. 2013. In Search of Mormon Identity: Mormon Culture, Gospel Culture, and an American Worldwide Church. International Journal of Mormon Studies 6: 1-53.

Embry, Jessie L. 1997. In His Own Language: Mormon Spanish-Speaking Congregations in the United States. Provo: Charles Redd Center for Western Studies, Brigham Young University.

Espiritu, Yen. 2001. We don't sleep around like white girls do: Family, culture, and gender in Filipina American lives. Signs: Journal of Women in Culture and Society 26: 415-40. [CrossRef]

Espiritu, Yen Le. 2003. Home Bound: Filipino American Lives across Cultures, Communities, and Countries. Berkeley: University of California Press.

Garcia, Ignacio M. 2015. Finding a Mormon Identity through Religion and Activism: A Personal Note on Constructing a Latino Time and Place in the Mormon Narrative. Journal of Mormon History 41: 69-90.

Garcia, Ignacio M. 2018. Thoughts on Latino Mormons, Their Afterlife, and the Need for a New Historical Paradigm for Saints of Color. Dialogue: A Journal of Mormon Thought 50: 1-30.

Garcia, Ignacio M. 2020. Lamanitas, The Spanish-speaking Hermanos: Latinos Loving Their Mormonism Even as They Remain the Other. In The Palgrave Handbook of Global Mormonism. Cham: Palgrave Macmillan, pp. 727-49.

Garrett, Matthew R. 2010. Mormons, Indians, and Lamanites: The Indian Student Placement Program, 1947-2000. Tempe: Arizona State University.

Gooren, Henri. 2007. Latter-day Saints under siege: The unique experience of Nicaraguan Mormons. Dialogue: A Journal of Mormon Thought 40: 134-55.

Hagan, Jacqueline, Rubén Hernández-León, and Jean-Luc Demonsant. 2015. Skills of the Unskilled: Work and Mobility among Mexican Migrants. Berkeley: University of California Press.

Hernandez, Daniel. 2021. A Divine Rebellion: Indigenous Sacraments among Global “Lamanites”. Religions 12: 280. [CrossRef]

Hinojosa, Felipe. 2014. Latino Mennonites: Civil Rights, Faith, and Evangelical Culture. Baltimore: Johns Hopkins University Press.

Hitt, Tarpley. 2019. The bizarre cult of\# DezNat: Alt-Right Mormons targeting porn and the LGBTQ community. Daily Beast. Available online: https: / www.thedailybeast.com/the-cult-of-deznat-alt-right-mormons-targeting-porn-and-the-lgbtq-community (accessed on 7 January 2021).

Holloway-Friesen, Holly. 2008. The invisible immigrants: Revealing 1.5 generation Latino immigrants and their bicultural identities. Higher Education in Review 5: 37-66.

Hondagneu-Sotelo, Pierrette. 1994. Gendered Transitions: Mexican Experiences of Immigration. Berkeley: University of California Press.

Hondagneu-Sotelo, Pierrette. 2008. God's Heart Has No Borders: How Religious Activists Are Working for Immigrant Rights. Berkeley: University of California Press.

Hondagneu-Sotelo, Pierrette, and Michael A. Messner. 1994. Gender displays and men's power. In Theorizing Masculinities. London: Sage, chp. 11. p. 200.

Jones, James C. 2019. Racism. Dialogue: A Journal of Mormon Thought 52: 203-8.

King, Farina. 2019. Indigenizing Mormonism. Mormon Studies Review 6: 1-16.

Lawson, Ronald. 1998. From American church to immigrant church: The changing face of Seventh-Day Adventism in metropolitan New York. Sociology of Religion 59: 329-51. [CrossRef]

Levitt, Peggy, and B. Nadya Jaworsky. 2007. Transnational migration studies: Past developments and future trends. Annual Review Sociology 33: 129-56. [CrossRef]

López-Sanders, Laura. 2012. Bible Belt immigrants: Latino religious incorporation in new immigrant destinations. Latino Studies 10: $128-54$

Marti, Gerardo. 2015. Latino Protestants and their congregations: Establishing an agenda for sociological research. Sociology of Religion 76: 145-54. [CrossRef]

Mason, Patrick Q. 2018. Mormonism and Race. In The Oxford Handbook on Race and Religion in America. Edited by Paul Harvey and Kathryn Gin Lum. New York: Oxford University Press, pp. 156-71.

Mauss, Armand L. 2003. All Abraham's Children: Changing Mormon Conceptions of Race and Lineage. Champaign: University of Illinois Press. 
Mccombs, Brady. 2020. Mormons Add Call to Eradicate Prejudice, Racism to Handbook. AP NEWS, December 18. Available online: https:/ / apnews.com/article/race-and-ethnicity-coronavirus-pandemic-1122b62368dbabb8b0ae3b1499220b95 (accessed on 12 January 2021).

McConkie, Bruce R., and Hans-Wilhelm Kelling. 1966. Mormon Doctrine. Salt Lake City: Bookcraft, vol. 97.

Menjivar, Cecilia. 2002. Living in two worlds? Guatemalan-origin children in the United States and emerging transnationalism. Journal of Ethnic and Migration Studies 28: 531-52. [CrossRef]

Menjivar, Cecilia. 2006. Introduction: Public religion and immigration across national contexts. American Behavioral Scientist 49: 1447-54. [CrossRef]

Molina-Guzmán, Isabel. 2010. Dangerous Curves: Latina Bodies in the Media. New York: NYU Press, vol. 5.

Moshin, Jamie, and Richard Benjamin Crosby. 2018. Liminally White: Jews, Mormons, and Whiteness. Communication Culture E Critique 11: 436-54.

Mueller, Max Perry. 2017. Race and the Making of the Mormon People. Chapel Hill: University of North Carolina Press.

Muro, Jazmín A. 2016. "Oil and water"? Latino-white relations and symbolic integration in a changing California. Sociology of Race and Ethnicity 2: 516-30. [CrossRef]

Murphy, Thomas W. 1999. From Racist Stereotype to Ethnic Identity: Instrumental Uses of Mormon Racial Doctrine. Ethnohistory 46: 451-80. [PubMed]

Nabhan-Warren, Kristy. 2014. The Virgin of El Barrio: Marian Apparitions, Catholic Evangelizing, and Mexican American Activism. New York: NYU Press.

Niemann, Yolanda Flores. 2016. Tokenism. In The Wiley Blackwell Encyclopedia of Gender and Sexuality Studies. Edited by Nancy A. Naples. Hoboken: John Wiley \& Sons, Ltd., ISBN 978-1-4051-9694-9.

Ong, Aihwa. 2003. Buddha Is Hiding: Refugees, Citizenship, the New America. Berkeley: University of California Press, vol. 5.

Phillips, Rick, Ryan T. Cragun, Barry A. Kosmin, and Ariela Keysar. 2011. Mormons in the United States 1990-2008: Socio-demographic Trends and Regional Differences. Hartford: Institute for the Study of Secularism in Society and Culture.

Reeve, W. Paul. 2015. Religion of a Different Color: Race and the Mormon Struggle for Whiteness. Oxford: Oxford University Press.

Reséndez, Andrés. 2016. The Other Slavery: The Uncovered Story of Indian Enslavement in America. Boston: Houghton Mifflin Harcourt Publishing.

Reyes, Raul A. 2016. The Future of the Mormon Church? It's Latino. NBCNews. August 22. Available online: https:/ /www.nbcnews. $\mathrm{com} /$ news/latino/future-mormon-church-it-s-latino-n570621 (accessed on 2 November 2020).

Riess, Jana. 2019. The Next Mormons: How Millennials Are Changing the LDS Church. Oxford: Oxford University Press.

Romanello, Brittany. 2020. Multiculturalism as Resistance: Latina Migrants Navigate US Mormon Spaces. Dialogue: A Journal of Mormon Thought 53: 5-31. [CrossRef]

Salazar, Miguel. 2019. The Problem with Latinidad. The Nation. September 16. Available online: https://www.thenation.com/article/ archive/hispanic-heritage-month-latinidad/ (accessed on 7 January 2021).

Sarat, Leah. 2013. Fire in the Canyon: Religion, Migration, and the Mexican Dream. New York: NYU Press.

Smith, Christopher. 2015. Race and the Mormon Struggle to Revise Whiteness. Worlds without End: A Mormon Studies Roundtable. Available online: http:/ / www.withoutend.org/race-mormon-struggle-to-revise-whiteness/ (accessed on 2 November 2020).

Spell, Sarah A. 2017. Not just black and white: How race/ethnicity and gender intersect in hookup culture. Sociology of Race and Ethnicity 3: 172-87. [CrossRef]

Stohlman, Sarah. 2007. At Yesenia's House. Qualitative Sociology 30: 61-80. [CrossRef]

Stuart, Joseph R. 2018. A More Powerful Effect upon the Body: Early Mormonism's Theory of Racial Redemption and American Religious Theories of Race. Church History 87: 768-96. [CrossRef]

Toomey, Russell B., Kimberly A. Updegraff, Adriana J. Umaña-Taylor, and Laudan B. Jahromi. 2015. Gender Role Attitudes across the Transition to Adolescent Motherhood in Mexican-Origin Families. Family Process Journal 54: 247-62. [CrossRef]

Vega, Sujey. 2019. Intersectional hermanas: LDS Latinas navigate faith, leadership and sisterhood. Latino Studies 17: 27-47. [CrossRef]

Waninger, Kelsey. 2015. The Veiled Identity: Hijabistas, Instagram and Branding in the Online Islamic Fashion Industry. Ph.D. thesis, Georgia State University, Atlanta, GA, USA.

Welborne, Bozena C., Aubrey L. Westfall, Özge Çelik Russell, and Sarah A. Tobin. 2018. The Politics of the Headscarf in the United States. Ithaca: Cornell University Press.

Yang, Fenggang, and Helen Rose Ebaugh. 2001. Religion and ethnicity among new immigrants: The impact of majority/minority status in home and host countries. Journal for the Scientific Study of Religion 40: 367-78. [CrossRef] 